Bangladesh J. Zool. 49 (2): 347-351, 2021

- Scientific Note

ISSN: 0304-9027

eISSN: 2408-8455

\title{
FEEDING AND BREEDING HABITS OF MANGROVE KINGFISHER (TODIRAMPHUS CHLORIS) IN THE SUNDARBANS RESERVE FOREST, BANGLADESH
}

\author{
Asif Ahmed \\ Department of Zoology, Faculty of Biological Sciences, University of Dhaka \\ Dhaka 1000, Bangladesh
}

From March 2017 to May 2018, a study was conducted on the feeding and breeding ecology of mangrove kingfisher in Satkhira Range of the Sundarbans. The Sundarbans is the largest single patch of mangrove woodland contributing to the different biotic and abiotic factors-soil formation, hydrological cycle, climate, and protection from natural disasters (Kathiresan and Bingham 2001). Among 12 kingfishers in Bangladesh, nine species of kingfishers including Todiramphus chloris are found in The Sundarbans (Rahman and Asaduzzaman 2010). Mangrove kingfisher has a bluish head, tail, and hindquarter; white ring on the neck that extends to the lower parts (Hoyo et al. 2001). In Bangladesh, Mangrove Kingfisher inhabits the tidal creeks, mangrove swamps, and forest edges along the coastline in Chattogram and Khulna division (Ahmed et al. 2008). The scientific name means green bird with a prominent bill (Ahmed et al. 2008). The bird can be identified by its loud, ringing, "kee" call (four times on average) (Hoyo et al. 2001).

Studies on the feeding and breeding ecology of this species are necessary, not only from a biological or ecological standpoint but also from the conservation and population management perspectives. The literature reveals a little information about mangrove kingfisher's life history. Researchers have studied a few anatomical, physiological and ecological attributes- the DNA barcoding, hunting method, population status and decline due to alien intruders, cooperative nesting molecular phylogeny niche partitioning- of mangrove kingfisher outside Bangladesh (Luczon et al. 2010, Fitzsimons et al. 2011, Pereira 2013, Beckon 1987, Campbell 2013, Anderson et al. 2015, Borah et al. 2012 ). No study has been done on the feeding and breeding ecology of mangrove kingfishers in Bangladesh. This short note would work as an ecological baseline database for mangrove kingfisher study and mangrove ecosystem of the southwestern part of the Sundarbans.

*Author for corresponding: <ahmedasifbd@gmail.com>

C2021 Zoological Society of Bangladesh DOI: https://doi.org/10.3329/bjz.v49i2.56269 
The study was undertaken from March 2017 to May 2018. The study was carried out in three nests, located in- Munshiganj forest office $\left(22^{\circ} 16^{\prime} 15.2^{\prime \prime} \mathrm{N}\right.$ $\left.89^{\circ} 11^{\prime} 50.2^{\prime \prime} \mathrm{E}\right)$; Bank of Chuna river $\left(22^{\circ} 15^{\prime} 10.3^{\prime \prime} \mathrm{N} 89^{\circ} 11^{\prime} 25.5^{\prime \prime} \mathrm{E}\right)$ and Kadamtola forest office $\left(22^{\circ} 13^{\prime} 44.7^{\prime \prime N} 89^{\circ} 10^{\prime} 52.1 " \mathrm{E}\right)$ under Munshiganj union Shyamnagar Upazila of Satkhira. Chuna river has separated Munshiganj union from the Sundarbans. Field trips were conducted fortnightly. Lines of Hijal (freshwater mangrove- Barringtonia acutangula), Keora (sonneratia mangrove- Sonneratia apetala) trees are found along the bank of the Chunar river which is an unpaved road. In Munshiganj forest station, I found Nipa palm (Nypa fruticans), Jackfruit (Artocarpus heterophyllus), Sundri (Heritiera fomes), Coconut (Cocos nucifera). The monsoon ranges from June to September and winter ranges from October to February in the Sundarbans (Rahman and Asaduzzaman 2010).

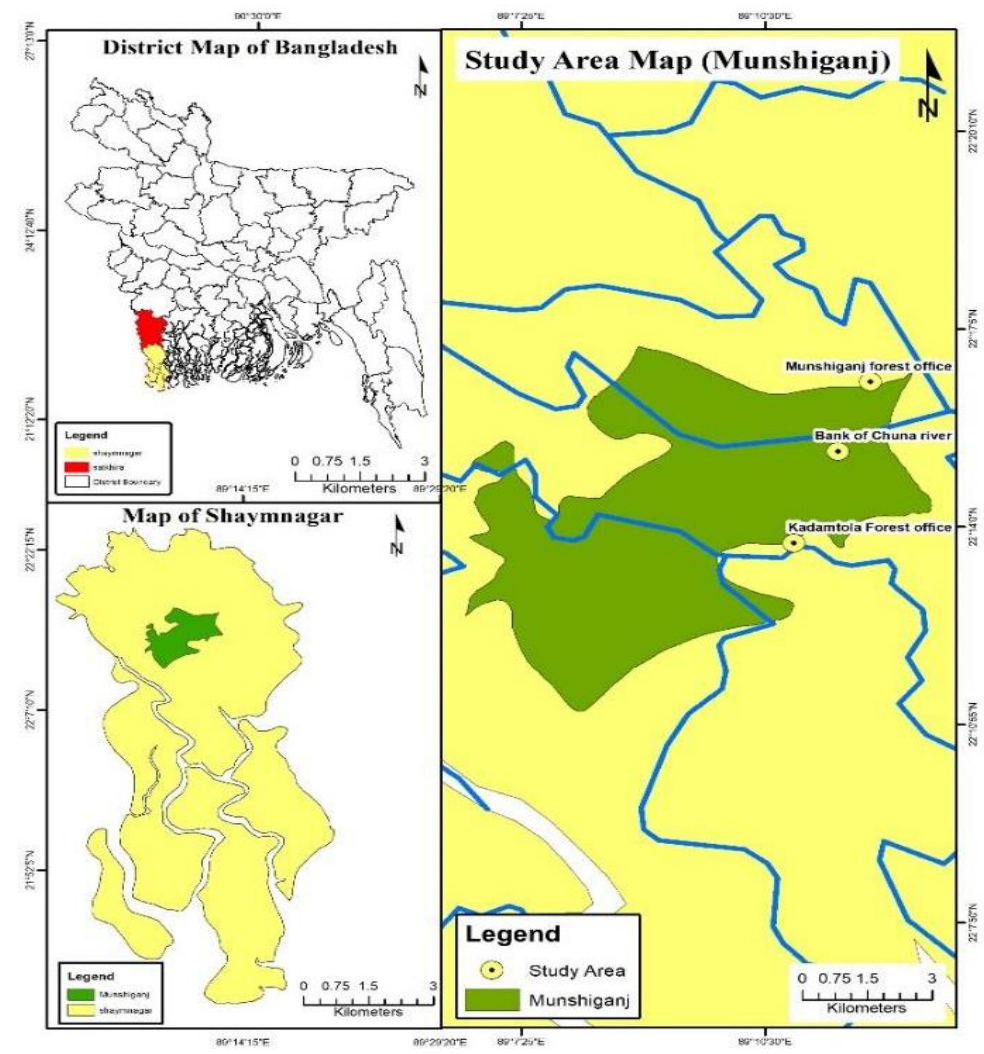

Fig. 1. Map of study areas.

Focal animal sampling method at 5 minutes intervals was followed to study and observe the feeding ecology of mangrove kingfisher (Altmann 1974). A total of 48 
days were spent in fieldwork. No nest was visited directly, due to the heavy rain and the high altitude location of the nest. Volunteers (two college student citizen scientists) were appointed to visit the nest on the bank of Chuna river twice a week in July and collected data on the nest, breeding behaviour and hatchlings. Secondary data were collected from thirteen (13) inhabitants and local anglers through a questionnaire survey. The questions were: what reproduction behaviors and interactions (chasing, food offering, mounting) did you observe?; What type of parental care (incubation, brooding and feeding hatchling) did they observe? and which other animals disturb the parent birds? Each nesting tree was marked by GPS coordinates when water level was low.

Mangrove Kingfisher showed sit-and-wait foraging technique with keen eyesight. Every single feeding $(n=91)$ includes conspicuous searching, diving, and prey handling. So the mangrove kingfisher can be termed as a specialist forager, not an opportunistic feeder. Its food items $(n=106)$ are crabs $(n=66$, $62.26 \%)$, minnows $(\mathrm{n}=13,12.26 \%)$ and shrimps $(\mathrm{n}=10,9.43 \%)$ chiefly. Among crabs, paddler crab (Metopograpsus messor) and ghost crab (Ocypode macrocera) were identified (Ahmed et al. 2008). Other twelve (12) individuals were unidentified. Paddler crab $(72.72 \%)$ was the highest preference. The bird spent 32.74 seconds $(\mathrm{SD} \pm 12.03)$ on average for a single feeding.

During the study period, the frequency of feeding was higher (2.43 times/day) in monsoon (June-September) and lower in winter (Oct-Feb) (2.31 times/day). The parents beat the crab against the branch of trees until the crab stopped moving. Then they provisioned it to the fledglings.

But the breeding behavior started to be observed from late February till July. As sexes were alike in mangrove kingfisher, it could not be possible to determine whether they were monogamous or polygamous. The bird pair nested solitarily. Parents became territorial after pair formation and nest selection in April-June. Pair formation occurred in mid-February. Two nests were built in the branchless portion of the trunk of two different blinding trees (Excoecaria agallocha) in Munshiganj Forest office and another one of Chuna river. The third nest was observed on a grey mangrove (Avicennia species) in Kodomtola. All the nests were previously made. Both partners defended the territory aggressively. In breeding season, they displayed agitated gestures and chased other birds (conspecies and other species), especially common myna (Acridotheres tristis) and crow (Corvus splendus). However, from the questionnaire survey it is known that mating behavior (mounting) was observed thrice in the second week of May at the nest tree in the bank of Chuna river. One clutch with four eggs was recorded in the 2nd week of June on the bank of Chuna river. One of which was spoiled and eaten by one parent including the shell and the shell was 
regurgitated later. After 17-20 days of incubation period, three eggs hatched in the first week of July. The newly hatched hatchlings were naked and blackish. After hatching the chick took 25-30 days to fledge. But they did not leave the nest immediately. Parents feed them and nurture them (secondary data). Whenever they could not grab the prey by their beak at the first attempt, they tried again sitting on the mud. Local people informed that children climbed up and took the eggs whenever a nest was accessible to them. Coastal belt plantation program took place in the riverbank of Chuna under the supervision of the Munshiganj Union Parishad.

\section{LITERATURE CITED}

AHMED, A.T.A., KABIR, S.M.H., AHMED, M., RAHMAN, A.K.A., HAQUE, E.U., AHMED, Z.U., BEGUM, Z.N.T., HASSAN, M.A. and KHONDOKAR, M. (eds). 2008. Encyclopedia of Flora and Fauna of Bangladesh. Vol 18. Part II. Arthorpoda: Crustacea. Asiatic Society of Bangladesh, Dhaka. 179-180 and 185-186 pp.

ALTMANN, J. 1974. Observational study of behavior: sampling methods.Behaviour 49(3): 227-267.

ANDERSEN, M.J., SHUlT, H.T., CIBOIS, A., THIABOUlT, J.C., FIlARDI, C.E. and MOYLE, R.G. 2015. Rapid diversification and secondary sympatry in Australo-Pacific kingfishers (Aves: Alcedinidae: Todiramphus). Royal Society Open Sci. 2(2): 140375.

BECKON, W.N. 1987. Evidence of cooperative nest excavation by the White-collared Kingfisher in Fiji. Ibis 129: 391-392

BirdLife International. 2016. Todiramphus chloris. The IUCN Red List of Threatened Species 2016: e.T22683399A95211137. Downloaded on 11 May 2018.

BORAH, J., GHOSH, M., HARIHAR, A., PANDAV, B. and GOPI, G.V. 2012. Food-niche partitioning among sympatric kingfishers in Bhitarkanika mangroves, Odisha. J Bombay Nat Hist Soc. 109: $72-77$.

CAMPBELL, O., AL ALI, A. and TOVEY, N. (2012). The status of Collared Kingfisher in the United Arab Emirates, with comments on the status of Sykes's Warbler and Indian Pond Heron. Tribulus 20: 62-66.

FITZSIMONS, J.A. and THOMAS, J.L. 2011. Fiji's collared kingfishers (Todiramphus chloris vitensis) do hunt for fish in inland waters. Notornis 58: 163-164.

HOYO, J., ELLIOT, A. and SARGATAL, J. 2001. Handbook of Birds of the World. Lynx Editions, Barcelona. Vol 6. 133-138 pp.

KATHIRESAN, K. and BINGHAM, B.L. 2001. Biology of mangroves and mangrove ecosystem. Advances in Marine Biology 40: 81-251.

LUCZON, A.U., ISA, A.H.M.M., QUILANG, J.P., ONG, P.S., and FONTANILLA, I.K.C. 2010. DNA barcoding of the White-Collared Kingfisher Todiramphus chloris (Boddaert 1783)(Alcedinidae) 
using the mitochondrial cytochrome c oxidase subunit I gene. Philippine Science Letters 2:7477.

MORGAN, R. and GLUE, D. 1977. Breeding, mortality and movements of Kingfishers. Bird Study 24(1): 15-24.

PEREIRA, J. 2013. Potential alien species threat for the Arabian Collared Kingfisher at its only UAE breeding locality. Tribulus 21: 38-42.

RAHMAN, M.R. and ASADUZZAMAN, M. 2010. Ecology of Sundarban, Bangladesh. Journal of Science Foundation 8(1-2): 35-47.

(Manuscript received on 20 April 2020 revised on 18 June, 2021) 